\title{
11 Indonesia's Direct Elections: Empowering the Electorate or Entrenching the New Order Oligarchy?
}

\author{
MARCUS MIETZNER
}

Despite its sudden collapse, Soeharto's New Order regime left behind important political legacies. These legacies, formed and consolidated over decades of autocratic rule, emerged as serious challenges to Indonesia's democratic transition after 1998. Most importantly, the political inheritance of the New Order included paradigms of highly centralistic rule and notorious distrust of electoral empowerment of the masses. This chapter will study a core element of the post-Soeharto reforms designed to address these legacies: the direct elections of governors, regents and mayors that began in June 2005. These ballots, which were launched in order to further increase the competitiveness of Indonesia's political system, led to the direct election of more than 300 local government heads by early 2007.

The remarkable persistence of crucial New Order legacies became evident in the discussions on political reform shortly after the regime change. Apparently, Soeharto's predilection for centralism had not only shaped the institutional outlook of his regime, but had also infiltrated the thinking of his opponents to a much larger extent than they were prepared to admit. Megawati Soekarnoputri, for example, who was seen by many Indonesians as a symbol of opposition to the Soeharto regime and was thus set to play a prominent role in post-New Order politics, shared much of Soeharto's instinctive dislike for decentralised governance and direct electoral mechanisms.

Consequently, it was not Megawati or other figures of Soeharto's 'semi-opposition' (Aspinall 2005) who drove the first initiatives for decentralisation and electoral reform after the 1998 regime change. Instead, political liberalisation was largely the result of reforms initiated by the deposed president's deputy and successor, B.J. Habibie (see Anwar, this volume). Originating from Sulawesi and educated in Germany, Habibie swiftly disentangled himself from Soeharto's Java-centric 
and uniformist ideology. Habibie deregulated the political party system within a week of assuming power, and pushed an ambitious decentralisation law through the New Order appointed parliament in 1999. The extraordinary nature of this transformation was highlighted by the slowing of political reform after Habibie lost power. Following the end of his 18-month interregnum in October 1999, it took almost three years (until 2002) for political leaders to agree on the direct election of the president, and another two (until 2004) to allow voters to elect their top executives in local government by direct ballot.

The direct elections of local government heads, introduced through law No 32/2004, completed the process of electoral liberalisation begun after Soeharto's fall. Instead of the authoritarian appointment policy of the Soeharto era and the political backroom maneuvering of the early post-New Order years, it was now the electorate that determined directly who headed their regional institutions of government. Despite the rocky and long-winded negotiations that preceded it, the reform was greeted by most political commentators as a breakthrough on the way to decentralised, democratic governance in Indonesia. It was expected to end the monopolistic grip of elites on the established channels for attaining top executive positions, instead providing popular grassroots leaders, civil society figures and academics with the opportunity to directly seek a mandate from the people.

These hopes have only been partially fulfilled, however. This chapter will analyse political and socio-economic patterns that emerged from the more than 300 polls held between mid-2005 and early 2007. In its first section, the chapter will briefly describe the mechanisms that were used to elect local government officials under the New Order and in the immediate post-Soeharto period, before discussing the changes introduced by law No 32/2004. Second, it will analyse the backgrounds of candidates participating in the direct ballots, allowing for an evaluation of the extent to which elites groomed under the New Order continued to maintain their hold on power. Third, the chapter will look at several trends reflected in the outcome of the elections, pointing to increased self confidence and maturity of the electorate. Finally, it will conclude that even though politico-economic elites nurtured during Soeharto's rule have indeed extended their influence into post-authoritarian politics, the introduction of direct local elections has empowered voters to determine the outcome of interelite competition for political office. While not representing a complete break with the elitist power relations nurtured by the New Order, this constitutes a significant step forward in Indonesia's democratic transition. 


\section{Local elections during the New Order and the post-authoritarian transition}

In its early years, the late 1960s and early 1970s, the Soeharto government used its emergency powers and sheer political weight to pressure the remaining political parties into endorsing the regime's choices for top positions of local government around the country. After the New Order's institutional framework was largely completed in the early 1970s, however, the election of local officials used law No 5/1974 as its legal foundation. Based on the law, local parliaments were entitled to draft a short-list of candidates for the positions of governor, district head (bupati) and mayor, which was subsequently handed over to the Ministry of Home Affairs. While the central government typically confirmed the candidate who had received the most votes in that selection process, the president reserved the authority to pick a different nominee for the position. The presidential veto right was not the only measure that restricted the nominal powers bestowed on local legislatures, however. Most significantly, the composition of parliaments was such that it was virtually impossible for a candidate not backed by the regime to get nominated, let alone elected. The government's electoral machine, Golkar, controlled comfortable majorities in almost all local legislatures, and the authorities intensively 'screened' parliamentarians from the other two parties sanctioned by the regime, the United Development Party (Partai Persatuan Pembangunan, PPP) and the Indonesian Democratic Party (Partai Demokrasi Indonesia, PDI), before they were allowed to take up their seats.

This combination of restrictive regulations and overwhelming political control ensured that in 24 years of local elections under law No 5/1974, very few surprises occurred. One of the rare exceptions was the gubernatorial election in Riau in 1985. In that year, one candidate - who had been nominated only for the usual ceremonial reason of ensuring there was more than one nomineeactually beat the favourite in the ballot, creating a nation-wide political uproar. The power apparatus of the regime was immediately set in motion to correct the 'error', however, and then Golkar Chairman Sudharmono forced the unexpected governor-elect to declare his resignation (Sudharmono 1997:353). In the few cases when such deviations from the established procedure took place, they were less an indication of the regime's weakness than of intensive competition within it. Thus Soeharto almost invariably managed to use his overwhelming authority to settle such controversies.

\section{Elections through local legislatures, 1999-2004}

Central government intervention into the elections of local executives largely ended when the Habibie administration enacted a number of political laws 
in 1999, including No 22 on Local Governance. The changes meant that after the parliamentary elections of June 1999, local legislatures with multi-party representation were free to elect new governors and district heads whenever their terms expired. The requirement to submit their preferred choice to Jakarta for approval was abolished.

The new institutional set-up did not result in the rapid replacement of New Order incumbents, however. Particularly at the provincial level, governors with strong ties to the fallen regime were able to defend their grip on power, even though they did not belong to any of the political parties that dominated local parliaments. In 2002 and 2003, the governors of Jakarta, Central Java, East Java, North Sumatra and East Kalimantan, who were all retired military officers, secured their re-election by their respective local legislatures (Honna 2005). Exploiting their vast financial resources and the fragmentation of the political party system, these governors managed to draw a majority of parliamentarians to their sides.

In his analysis of this phenomenon, Harold Crouch (2003) argued that obviously party politicians calculated that 'it is better to re-endorse a military officer ... than to risk the election of governors from rival parties'. Even in cases where no incumbent stood for re-election, contested local executive posts mostly went to well-entrenched individuals with bureaucratic or military backgrounds, rather than to leaders of parties who participated in the 1999 elections. Apparently, the patterns of electoral behaviour in the post-authoritarian transition were not dissimilar to those of the early New Order when, according to Ulf Sundhaussen (1978:52), 'many provincial and district assemblies favoured the appointment of colonels and generals, even ... when political parties still had an important say in these assemblies'. The major reason for this was 'the reluctance of party politicians to back a candidate from a rival party; they would rather vote for someone who is considered 'neutral' in party politics'.

\section{Direct elections: the reforms of 2004}

The success of New Order figures in retaining their posts, amidst allegations of vote buying and corruption, increased the pressure on the government to further deregulate the electoral system. After provisions for the direct election of the president and vice-president were adopted through constitutional amendments in 2002 and executed in 2004, the administration of Megawati Soekarnoputri enacted law No 32 on Local Governance in its final days in office. According to the new law, governors and district heads were to be elected directly by the people. The authority to nominate candidates was limited to political parties that in the 2004 polls had gained 15 per cent of the votes or parliamentary seats in the relevant electoral area. Independent candidates were not allowed 
to run. ${ }^{1}$ Local Electoral Commissions (Komisi Pemilihan Umum Daerah, KPUD) were tasked with conducting the polls, marginalising the national KPU that had organised the 2004 ballots. Funding was to come mostly from local budgets, with unspecified contributions from the central government.

As the government had declared a moratorium on the election of local government heads by legislatures for 2004, pending the presidential polls and the enactment of the new law, a wave of 173 direct elections was scheduled for June 2005, with subsequent ballots occurring whenever the term of an incumbent expired. The prospect of the first direct elections of local government executives in Indonesia's history created high expectations, both in political circles and at the grassroots. The Asia Foundation's 'Indonesia Rapid Decentralization Appraisal' (2004:12) predicted that the polls would 'enhance democracy at the local level'. It stated that 'Indonesians eagerly welcome this development' and detected a strong public expectation that 'candidates who are believed to be corrupt will not get elected' (The Asia Foundation 2004:34). The following section will analyse the background of the candidates eventually nominated for the polls, indicating that despite the widespread optimism, entrenched politico-oligarchic elites proved well positioned to defend their control over local government institutions.

\section{Entrenchment of the oligarchy: candidates, power and resources}

As political parties began in early 2005 to nominate candidates for the upcoming local polls, it quickly became clear that the new electoral rules would not drastically change the composition of the political and economic elites competing for positions of power. Similar to the trend under the old electoral mechanism (Malley 2003), influential bureaucrats, rich businesspeople and retired security officers emerged as the top contenders for the nominations.

There were several reasons for this development. First, local party branches, which had the right to nominate candidates, recognised that offering nominations to individuals with the greatest monetary resources represented an opportunity for them to consolidate party finances. The three rounds of national elections in 2004 had left most local party offices cash-strapped, while there was no effective system of state-sponsored party financing in place to refill the coffers. Faced

1 The law reserved exclusive rights for the special autonomy areas of Aceh and Papua, however. In Papua, candidates had to be native Papuans in order to qualify as nominees, and based on the new law on the Governance of Aceh passed in July 2006, independent candidates had the right to run in the local elections of Aceh, which were held in December of that year. 
with another costly election, most party leaders opted to shift the financial burden of the campaign to affluent nominees and to pocket some additional money in the process.

Second, parties often lacked credible candidates from their own ranks. There was a widespread view within the elite and the public that candidates for executive office needed to have extensive bureaucratic experience, and very few party politicians did so (Forum Rektor Indonesia, Press Release, 29 June 2005). Many party officials knew how to run a political organisation and mobilise grassroots support for it, but they typically lacked expertise in management, budgeting or government administration.

Third, the fact that most bureaucrats, entrepreneurs and retired officers who put themselves forward as candidates had close ties with the New Order regime did not reduce their popularity with the electorate. In fact, many voters even believed that such figures would be better positioned to provide stability, economic benefits and bureaucratic efficiency than inexperienced politicians, grassroots leaders or academics. ${ }^{2}$

\section{The candidates: socio-economic profiles}

The inclination of political parties to surrender the nominations to non-party figures was borne out in the socio-economic profiles of the candidates. The strongest group in the field of nominees was that of the career bureaucrats, who made up around 36 per cent of all candidates (Mietzner 2005). ${ }^{3}$ The group included incumbent and former governors and vice-governors, district heads and their deputies, executive secretaries (sekretaris daerah) as well as heads of government offices (kepala dinas). These key bureaucrats controlled large financial resources, had extensive networks in business and civil society, and had the advantage of high name recognition. Significantly, they would often form joint tickets with wealthy businesspeople who had little political experience but did possess the necessary cash to provide additional campaign funds and create an effective apparatus of supporters. Twenty-eight per cent of

2 During the presidential elections of 2004, surveys showed that 45 per cent of the electorate thought that an active or former general was best qualified for the presidency, as opposed to 14 per cent who favoured a religious leader and 9 per cent who wanted a human rights activist as president. Only 8 per cent of respondents believed a professional politician should become president (International Foundation for Electoral Systems 2004).

3 This data is based on a sample I took of 50 local elections in the first wave of polls that took place in June and July 2005. The information on the socio-economic and professional backgrounds was drawn from newspaper articles (mostly Kompas and Media Indonesia, which ran special sections on the elections), and personal observations of ballots in Kalimantan, Sulawesi, Java and Papua. Additional samples taken from other elections after July 2005 suggest that the figures presented here reflect broad and stable patterns as far as the profiles of the candidates are concerned. 
all candidates belonged to this latter category. The combination of politically entrenched bureaucrats and rich entrepreneurs was so powerful that according to one statistic, such pairs won 87 per cent of all local polls (Rinakit 2005).

The third group consisted of party politicians and members of parliament, who represented 22 per cent of the nominees. This category included businesspeople as well, however, who had taken up leadership positions in political parties and won seats in local legislatures well before the direct elections, often precisely in order to prepare their candidacy. Eight per cent of the candidates were retired or active military and police officers. ${ }^{4}$ While they were mostly lower ranking personnel, several former top generals contested the elections as well, including in Aceh, Papua, Jakarta and North Sulawesi. Finally, the smallest group of candidates consisted of academics, grassroots activists, religious leaders and media figures, constituting only six per cent of all nominees. While some such individuals were hugely popular in their home areas, they rarely had the funds to buy nominations from political parties or pay for large electoral machines.

The dominance of entrenched socio-economic elites in the nomination process was further demonstrated by the personal affluence of the candidates. In many cases, local election commissions published the wealth reports, which nominees had handed in as part of their registration process. These reports provided interesting insights into the assets of candidates on the one hand and the varied psychology of contestants on the other. Incumbents or holders of other key government positions tended to under-report their fortunes, fearing that they would be accused of having enriched themselves while in office if they revealed extensive personal wealth. Some challengers, however, saw an advantage in having their wealth fully reported, apparently believing that voters might view genuine personal affluence as a safeguard against corruption. For example, in the 2005 election for mayor of Manado, the capital of North Sulawesi, three candidates reported assets in excess of one million dollars, with two others well above the half-million-dollar mark (Harian Komentar, 16 June 2005).

By contrast, the governor of the province A. J. Sondakh, who stood for reelection at the same time, declared a personal wealth of only 3.4 billion rupiah (around 350,000 USD). His announcement led to widespread cynicism and ridicule, given that Sondakh was at the centre of an alleged corruption scandal in which 18.3 billion rupiah of government funds had simply disappeared (Media Indonesia, 13 December 2004). The local newspaper Manado Post found it 'amusing' that Sondakh had admitted to the ownership of just one used car worth a meager 60 million rupiah (around 6,300 USD) (Manado Pos, 3 June

4 In November 2006, the military leadership announced that officers had to retire from active service before participating in elections. Previously, they only had to seek permission from Armed Forces headquarters and stand down from their institutional positions for the time of the campaign. 
2005). Fortunately for Sondakh, many of his opponents had their own issues with under-reporting. Wenny Warouw, an active police brigadier-general and candidate of the Christian party, the Party of Peace and Prosperity (Partai Damai Sejahtera, PDS), initially refused to report his wealth, which was estimated at around 50 billion rupiah (around 5.3 million USD). His assets were believed to include plantations in Minahasa, property and shares in Batam, an apartment in Perth, houses in Jakarta and Manado, and dozens of cars (Manado Pos, 30 May 2005). Warouw only published his wealth report several days before the polls, admitting ownership of assets worth 10 billion rupiah. Once again, the public groaned in disbelief (interviews in Manado, June 2005).

\section{Fund-raising and lobbyism}

Despite their sometimes massive personal assets, candidates were often in need of more funds. Observers have estimated that the cost of campaigning for the governorship could reach 100 billion rupiah, while nominees for the post of district head needed to prepare between 1.8 to 16 billion rupiah (Rinakit 2005:2). The money was needed to pay off the functionaries of nominating parties, establish a network of campaign offices, hire thousands of helpers, finance advertising campaigns in the media, employ public relations consultants and opinion pollsters, train and provide wages for monitors at the polling stations, as well as pay for entertainers at public events. The winner of the elections in the Sula archipelago, a district in North Maluku which has only 108,000 inhabitants, admitted that he spent 5 billion rupiah on the campaign, with only very little contributed by his nominating party, Golkar (interview with Ahmad Hidayat, November 2006). These costs were, in fact, significantly higher than under the previous electoral system, when interested candidates 'only' needed to pay a bare majority of legislators to get elected.

In order to raise additional funds, candidates running in the direct elections often entered into coalitions with business tycoons who did not want to stand in the elections themselves. In the 2005 gubernatorial elections in South Kalimantan, for example, most candidates received massive campaign contributions from influential coal mining magnates, who were eager to place sympathetic politicians in the governorship. Once in office, their protégés would then be expected to help with processing licenses and shielding their companies from investigations into the environmental damages caused by the large-scale mining operations in the province. One candidate, M. Ramlan, was even a coal-mining entrepreneur himself. He had to pay more than a dozen political parties to get nominated, and convinced a former provincial secretary to run as his deputy in order to compensate for his own lack of bureaucratic experience. Ramlan's main business rival, H. Abidin, spared himself such stress. Instead, he reportedly 
bankrolled the campaign of Rudi Ariffin, the long-time bupati of Banjar, who was the eventual winner of the elections and became new governor of South Kalimantan (interviews in Banjarmasin, May 2005).

\section{Party-candidate relations: the insignificance of ideology}

Getting hold of sufficient financial resources was such a high priority both for the candidates and the parties that nominated them that the political or ideological orientation of the nominee usually became a matter of secondary concern. Party leaders often declared that the nomination process was 'open for everyone', proudly describing it as an act of grassroots democracy. Senior party officials typically interviewed a wide variety of applicants for nomination, with candidates reporting that most questions focused on how much money they would be able to spend on the campaign and how much they were willing to 'donate' to the party.

The candidates, on the other hand, often applied with several parties before settling on the one that offered the lowest nomination costs and the most effective campaign network. Businessman Erlangga Satriagung, for example, who was interested to run in the 2005 mayoral elections in Surabaya, initially had approached the Party of National Awakening (Partai Kebangkitan Bangsa, PKB) (interviews in Surabaya, May 2005). The party was closely associated with the largest Muslim organisation in the country, Nahdlatul Ulama, and a key political force in the city. After learning the sum it would cost him to secure PKB's nomination, however, Erlangga entered into negotiations with the National Mandate Party (Partai Amanat Nasional, PAN). PAN, the political wing of the modernist Muslim group Muhammadiyah and often at loggerheads with the traditionalist PKB, was a much smaller party in Surabaya and thus a more affordable option for Erlangga. The local PAN elite eventually nominated Erlangga, drawing protests from party officials at the grassroots who claimed that he had paid bribes to their leaders. In the elections, Erlangga was soundly beaten by incumbent Bambang D.H., who had for long contemplated whether he should form a coalition with the puritan Muslim party, the Prosperous Justice Party (Partai Keadilan Sejahtera, PKS) or the Christian PDS, but finally had invited the editor-in-chief of East Java's largest newspaper to become his running mate (Jakarta Post, 27 June 2005). Ideological considerations, it turned out, took a backseat to tactical calculations, especially those concerned with gaining access to critical campaign resources and infrastructure.

The financial stakes involved in the nomination of candidates also explained the ferocity of intra-party conflicts in the pre-election period. In many cases, parties that had the right to name candidates fractured into several groups, with each of 
them promising the nomination to a different candidate. Often these antagonisms occurred between the central leadership of a party and its local branch, but they sometimes also ran through the local chapters themselves. The electoral law had granted the authority to nominate candidates to local party branches, but central leadership boards had the option of dismissing their functionaries in the regions if they did not support the nominee endorsed by the centre. Central party boards exercised this option in a couple of high-profile cases, with questionable success. President Susilo Bambang Yudhoyono's Democratic Party (Partai Demokrat, PD), for example, objected to the gubernatorial nominee appointed by its North Sulawesi branch, but after a series of crisis meetings in Manado during which local party members threw chairs at PD politicians from Jakarta, the provincial branch prevailed with the nomination of its candidate (Kompas, 24 March 2005). In Banten, Marissa Haque, a prominent PDI-P politician who sought the nomination of her party for Banten's gubernatorial race in 2006, felt so intimidated by her internal party rivals that she called them a bunch of 'criminals, drunks and gamblers' (Koran Tempo, March 2006). Eventually she left PDI-P, ran for another party and lost the election. Frequently it was the local KPUD that had the difficult task of deciding the outcome of such intra-party disputes, but in some cases, the matter even went before the courts. Once such disputes were resolved, the losing factions often had a difficult time fending off demands for financial compensation from those candidates who had paid them considerable amounts of money to get nominated. A small number of failed nominees even filed police reports to reclaim their investment (Kedaulatan Rakyat, 23 May 2005).

\section{Commercialisation and de-ideologisation}

It was this commercialisation of the nomination process and the insignificance of ideological affiliations within it that provided a space for former New Order elements to use the new democratic framework to their advantage. They had the resources and the bureaucratic experience necessary to stand in the polls, leaving newcomers to the political game with little chance to compete. Benefiting from the structural deficiencies of political parties and their indifference towards ideology, members of the entrenched elite could choose between several electoral vehicles before closing a deal with one of them.

In fact, the new institutional set-up allowed more former New Order bureaucrats to compete for top executive positions than under Soeharto's rule. Back then, Golkar was the only political platform for bureaucrats to aspire for higher office. Under the 2004 electoral laws, however, Golkar-affiliated bureaucrat-politicians who had not succeeded in gaining the nomination of their own party were free to apply with Golkar's competitors. Consequently, most candidates in the local polls had previous or existing connections with Golkar. In Papua, for instance, PDI-P's candidate for the 2006 gubernatorial elections was appointed to Golkar's 
national advisory board in the middle of the campaign. In North Sulawesi, all five candidates for the governorship had been affiliated with Golkar before the polls but had sought alternative options after Sondakh had secured his re-nomination by the party. During the campaign, the party split into several factions, with large sections supporting candidates other than Sondakh. Such cases highlighted the fact that the introduction of direct local elections has not significantly altered the composition of Indonesia's politico-oligarchic elite. Instead, it has increased the competition between its various elements, and has handed voters the authority to determine the outcome of such intra-elite competition.

\section{Empowering the electorate: the declining importance of incumbency and primordialism}

Despite the dominance of entrenched elites in the nomination process, the direct elections introduced important changes to the way political power is obtained in post-Soeharto Indonesia. These changes were visible in a number of trends that emerged from the results of many of the polls. In some cases, these trends confounded predictions made by observers before the elections, especially those regarding the role that incumbency and primordial sentiments would play in determining electoral outcomes.

To begin with, widespread fears that incumbents would easily ride to victory proved unfounded, with around 40 per cent of office holders losing their jobs. ${ }^{5}$ Incumbents' control of huge campaign funds, government resources and bureaucratic networks certainly was an advantage. More often than not, however, their competitors matched such advantages. Because in most local elections more than one senior bureaucrat competed, with each having access to a particular segment of the government apparatus, it was generally not possible for a single actor to manipulate the electoral administration. Keeping each other in check, the candidates would report attempted manipulations by their competitors to the press and election monitors.

While electoral manipulation and logistical mismanagement undoubtedly took place (ranging from poor voter registration mechanisms to errors in vote-counting procedures), in most elections such problems did not appear to significantly influence the outcome. This was not only because incumbents had relatively limited opportunities to control the process, but also because electorates often

5 A list of 103 polls at the district level showed 65 incumbents winning and 38 losing the elections. At the provincial level, the trend was similar. Out of nine governors standing for re-election in 2005 and 2006, four lost. Media Indonesia, 19 July 2005. 
issued such powerful and unambiguous verdicts that occasional manipulations only had a marginal effect on the end result. Paying close attention to the trackrecords of nominees, voters did not hesitate to throw out poor performers, often with overwhelming clarity. Many incumbents whose reputation had been damaged by allegations of corruption and nepotism were removed from office, including governors Sondakh in North Sulawesi, Sjachriel Darham in South Kalimantan, Asmawi Agani in Central Kalimantan and Aminuddin Polulele in Central Sulawesi. In some cases, continued public pressure after the electoral loss of incumbents even led to legal investigations into irregularities that occurred during their time in office. Sjachriel, for example, was charged with corruption and eventually arrested in January 2007.

\section{Winners and losers}

The removal of unpopular incumbents was in many places accompanied by the election of candidates with more attractive performance records. This trend demonstrated that despite the fact that nominees often had almost identical politico-economic backgrounds, the voters were still able to detect significant differences between them and make an informed choice. Accordingly, unlike their non-performing colleagues, successful incumbents were often returned to power, in some cases even with large margins. For example, the governor of Jambi, Zulkifli Nurdin, who had impressed voters with his unconventional style of governance, was re-elected in 2005 with around 80 per cent of the votes. Rustriningsih, one of the few female bupatis in Indonesia and exceptionally popular with the grassroots, achieved a similar result in the regency of Kebumen in Central Java. In West Sumatra, Gamawan Fauzi, the former bupati of Solok and recipient of a prestigious anti-corruption award, won the governorship against a highly competitive field of candidates. Similarly, Sinyo H. Sarundajang, a former acting governor of Maluku and North Maluku who had played an important role in restoring stability in these conflict-ridden provinces, won the gubernatorial race in his home region of North Sulawesi. In the elections, Sarundajang beat the incumbent, A. J. Sondakh, as well as a retired military officer, an active police general, and a member of the powerful Baramuli family-all of whom had financial resources and political networks that equaled or exceeded those of Sarundajang.

Not all of the winners were shining examples of clean and accountable government, of course. Many of the incumbents who secured re-election had simply made sure that the populace was sufficiently satisfied with the services provided by their governments, such as affordable health care, low school fees or food subsidies. Particularly in territories with high revenues from resource industries, this was not too difficult to achieve. In general, if incumbents could deliver basic services, the electorate appeared willing to tolerate a certain extent of self enrichment by them. In Kutai Kartanegara in East Kalimantan, for 
example, the incumbent bupati Syaukani H. R. won the 2005 district elections despite his well-known predilection for luxury treats, which included keeping Australian racehorses in air-conditioned stables (Jakarta Post, 4 June 2005). In spite of his extravagant lifestyle, however, Syaukani had not only used the district's oil and gas revenues for himself; he had also ensured that enough spoils trickled down to the voters for him to maintain an advantage over his electoral competitors (Jakarta Post, 2 June 2005). ${ }^{6}$ In the same vein, some challengers gained office not necessarily because of their own clean trackrecord, but because of the unpopularity of the incumbent. Again others succeeded because they were connected to high-ranking officials in their respective province or even in Jakarta, convincing the electorate that they would be able to secure more budget allocations for their home areas. ${ }^{7}$ However mundane their motivations may have been, voters mostly demonstrated that they possessed a clear understanding of their own interests. In some cases these interests included clean and transparent government, in others effective deliverance of services was apparently sufficient.

\section{The defeat of primordial exclusivism}

The increased maturity of the electorate was not only reflected in its determination to replace unpopular incumbents, but also in its inclination to reject candidates who campaigned on exclusivist platforms. Prior to the polls, many observers had been concerned that nominees might aim to attract voters by appealing to their partisan instincts, such as identification with a certain religion, ethnic group or family clan. Particularly in areas with heterogeneous populations, it was feared that some candidates could be tempted to mobilise their various core constituencies by fueling prejudices and sentiments against rival social groups.

In most cases, such primordialist out-bidding did not occur. Instead, candidates in heterogeneous regions tended to form cross-cultural tickets, addressing the moderate attitude of the electorate and hoping to gain additional votes from alternative constituencies. All nominees for the post of bupati in the multireligious and conflict-ridden district of Poso in Central Sulawesi, for example, linked up with running mates from a different faith. In 1999, the bupati elections in Poso had triggered bloody clashes between Muslims and Christians, who both claimed the leadership of the district for their group. In the 2005 elections, by contrast, the nomination of pairs from both faiths ensured that allegations of religious favouritism were effectively neutralised as an electoral issue (Media Indonesia, 8 May 2005). Similarly, nationwide statistics showed that coalitions

6 His convincing electoral victory did not prevent the authorities from pursuing legal investigations into his almost monarchical style of governance, however. In early 2007, he was under such pressure by investigators that he chose to seek long-term medical treatment in order to escape arrest.

7 One such was case was the victory of Ichsan Yasin Limpo in the district elections of Gowa in South Sulawesi. He was the brother of South Sulawesi's vice-governor Syahril Yasin Limpo. 
between Islamic parties were much less frequent than alliances between Islamic and secular-nationalist parties, with the latter accounting for 37 per cent of all nominations (Ramage 2007).

The pluralist composition of electoral teams in areas with complex demographic structures even managed to lift some representatives of minority groups into top executive positions. In Belitung Timur, for example, a Chinese Christian was elected as bupati in 2005 in a district in which the Islamist party Bulan Bintang was the strongest political force. In the same year, the Christian politician Teras Narang won the governorship in Central Kalimantan, a predominantly Muslim province. While there were initially concerns that newly elected local government heads from ethnic or religious minorities would find it difficult to maintain power without risking major social tensions, after two years in office these fears have largely proven unfounded.

In the few cases in which nominees did try to campaign with exclusivist programs, the electorate tended to reject them. The candidacy of Professor Usop in Central Kalimantan in 2005 provided important insights in this regard. Usop, a self-proclaimed leader of the Dayak, Central Kalimantan's largest ethnic group, had participated in gubernatorial elections before (International Crisis Group 2001). In 2000, when the governor was still elected by the local legislature, he had lost to Asmawi Agani by only a very small margin. One year after his narrow defeat, Usop had been arrested for his infamous role in instigating the largescale massacre and eviction of Madurese migrants, but he had to be released when his supporters threatened to storm the prison in which he was held. In the 2005 campaign, Usop emphatically argued against the return of the expelled Madurese, apparently believing that this populist message would carry him to victory. Instead, he finished last with only four per cent of the votes. Many Central Kalimantans obviously held him responsible for the negative image that their province had obtained as a result of the 2001 violence, and were not keen to risk further tensions by handing Usop the governorship (interviews in Palangkaraya, May 2005).

In the same vein, voters in North Sulawesi rejected attempts by the struggling incumbent A. J. Sondakh to exploit his leadership position in the province's largest church for campaign purposes. Cornered by corruption allegations, Sondakh declared that every governor of North Sulawesi had to be a leading member of the Minahasa church (Gereja Masehi Injili di Minahasa, GMIM), in which he was a senior official. Sondakh pointed out that S. H. Sarundajang, his major rival, was not active in GMIM, implying that he thus did not qualify for the governorship. Ultimately, Sarundajang won the elections in a landslide, demonstrating not only Sondakh's unpopularity, but also the indifference of voters towards the congregational affiliations of nominees. 


\section{Post-election protests: sour losers and unimpressed courts}

The moderation of the electorate was also the main reason for the absence of communal violence during the course of the elections. In none of the areas in which local elections were held did religious, ethnic or social groups clash as a result of the polls. Even in areas with long histories of communal tensions, like Kotawaringin Timur in Central Kalimantan, Ambon in Maluku or several districts in Central Sulawesi, the elections passed without significant disturbances to the relationship between the various key constituencies. The occasional eruptions of violence, which drew much media attention and gave the polls a rather chaotic public image, were largely contrived and lacked deep social roots. In most cases, crowds bankrolled by losing candidates besieged the offices of electoral bodies, smashing furniture and demanding that the poll results be annulled. In its most extreme forms, these protests led to the burning of government offices or the blocking of major roads with felled trees. These violent actions invariably died down, however, after it became clear that the vast majority of voters accepted the outcome of the polls and thus saw no reasons to join the protest.

In addition, the central government and the courts issued firm reminders that organised protests could not pressure them into overturning the results announced by the respective KPUDs. ${ }^{8}$ The Ministry of Home Affairs, for its part, declared that it had no authority to annul or alter election results, and judges were generally little impressed by the arguments brought forward by losing nominees, and tended to throw out their lawsuits. Even in the districts that witnessed the most extensive outbreaks of election-related protests, such as Kaur in Bengkulu and Tana Toradja in South Sulawesi, the results of the polls were reconfirmed and the organisers of the demonstrations eventually withdrew their troops.

Finally, voters also did not confirm widespread predictions that active and retired military officers would do exceptionally well in the polls, paving the way for the remilitarisation of Indonesian politics. In the run-up to the 2005 ballots, TNI Commander General Endriartono Sutarto had allowed six active officers to stand as candidates in the elections, leading to a heated debate among

8 Only in one prominent case, the mayoral elections of Depok in West Java in 2005, did judges overturn an election result, using blatantly flawed arguments. The Supreme Court, however, annulled that verdict in 2006 and removed the judges who had issued it. In another, less high-profile case, the High Court of Papua overturned the result of the 2005 district elections of Mappi, and the Supreme Court confirmed that decision. Apparently, the KPUD of Mappi had excluded the results of two villages from its count after protests from locals that the winner of the elections was an 'outsider'. The annulment of the results from the two villages moved the candidate favoured by the protesters ahead by a few votes, and thus avoided more violent demonstrations. The courts accepted, however, that the annulment of the disputed votes was politically motivated, and reinstated the initial winner. Interview with Johannes Bonay, member of the KPUD Papua, Jayapura, July 2005. 
politicians and observers if this constituted a signal for the military's return to the political arena (Kompas, 12 May 2005). In the end, none of the six candidates was elected to office. While a small number of former military leaders won their elections, including the races for governor in Central Sulawesi and West Irian Jaya in 2006, many more of their comrades were unsuccessful. Candidates with a military background suffered crushing defeats in the gubernatorial elections in Aceh, Papua and North and West Sulawesi, with some of them finishing last. Apparently, the former commanders found it difficult to grasp the very diverse dynamics of electoral politics at the local level, where cashed-up bureaucrats or charismatic society leaders often had easier access to the electorate than retired military officers offering old-fashioned security concepts.

The mixed performance of military officers in the polls has raised doubts over whether members of the Armed Forces will be able to defend their grip on some of their provincial strongholds after the terms of the current governors expire. By early 2007, retired officers elected through the old electoral mechanism still held the governorships of Jakarta, Central and East Java, South Sulawesi and East Kalimantan (the governor of North Sumatra, also a former general, died in a plane crash in September 2005 and was replaced by a civilian). All these areas will hold direct elections in 2007 and 2008, and if the outcomes of the polls conducted so far are anything to go by, the military will lose further ground as far as its hold on key positions in local government is concerned.

\section{Conclusion: new rules for the old elite}

The analysis of Indonesia's first direct local elections has produced two equally strong, but divergent set of conclusions. First, the new electoral mechanism has brought few changes to the composition of Indonesia's ruling elite. Participation in the polls required major financial resources and extensive connections within the entrenched political class. This, in turn, provided bureaucrats groomed under the New Order and affluent entrepreneurs with an unassailable advantage over potential newcomers. The nomination process exposed the structural weakness of the existing political parties, with independent and wealthy figures purchasing their candidacies from cash-strapped party boards. Thus one of the crucial preconditions for establishing a functioning democracy was not fulfilled, namely 'that a range of political parties not only represent interests but seek by coherent programs and organisational activity to aggregate interests' (Linz and Stepan 1996:274). In Indonesia's local elections, parties often nominated candidates without any previous relationship to them or their politico-ideological agendas, so long as the nominees could raise the necessary cash to fund their own campaigns and, most importantly, satisfy the financial 
needs of party officials. As a result, voters could find almost no link between the politico-ideological viewpoints that parties were supposed to aggregate, and the candidates who were nominated by them.

These deficiencies in the party system further consolidated the towering dominance of entrenched elites, producing a very narrow field of candidates running for office. With lower-class candidates and even elite outsiders largely excluded from the electoral competition, Indonesia's direct local polls lacked what Larry Diamond and Leonardo Morlino (2004:24-25) called one of the 'substantive dimensions' of democracy: political equality. Diamond and Morlino argue that 'to enjoy political equality, citizens must ... have some measure of equality in income, wealth, and status.' In Indonesia, however, the local elections revealed a yawning gap between those few who could afford to be politically active and the overwhelming majority who could not. This and other shortcomings inspired some of the more negative accounts of Indonesia's direct local elections (Rinakit 2005; Choi 2005), most of which argued that the polls were rather shallow procedures without much democratic substance.

The second conclusion, however, suggests that from the limited pool of nominees, voters generally picked candidates with better trackrecords and higher credibility as far as their promises to further voters' interests were concerned. Incumbents struggling with allegations of corruption were typically thrown out if they could not compensate for their greed by delivering satisfactory public services to the electorate. The incumbent turnover rate of 40 per cent, which is high even if compared to consolidated democracies, indicates that voters took some pleasure in punishing executive leaders they deemed unfit for office. In the same vein, candidates who were unable to explain convincingly their personal wealth or professional qualifications saw their chances of winning the ballot drastically reduced.

Furthermore, voters showed considerable maturity by rejecting platforms based on exclusivist primordial sentiments. More often than not, they opted for combinations of nominees who had varied religious and ethnic backgrounds, and generally accepted the defeat of the candidate they had supported in the ballot. The new self confidence of the voters was also reflected in electoral participation rates that, at a national average of 69 per cent, corresponded to healthy European standards. This was despite the often chaotic organisation of the polls by local authorities, who had difficulties in registering voters on time and explain the electoral rules to the public.

In summary, the local elections have empowered Indonesian voters to have a significant say in the outcome of inter-elite competition for political and economic power. While the composition of that elite remains largely unchanged, new governors or district heads swept into office by the elections are likely 
to pay more attention to the interests of the electorate than their predecessors did. The fate of many unpopular incumbents during the recent polls should be incentive enough.

Figure 11.1: Politico-Economic Backgrounds of Candidates (data from 20 selected polls)

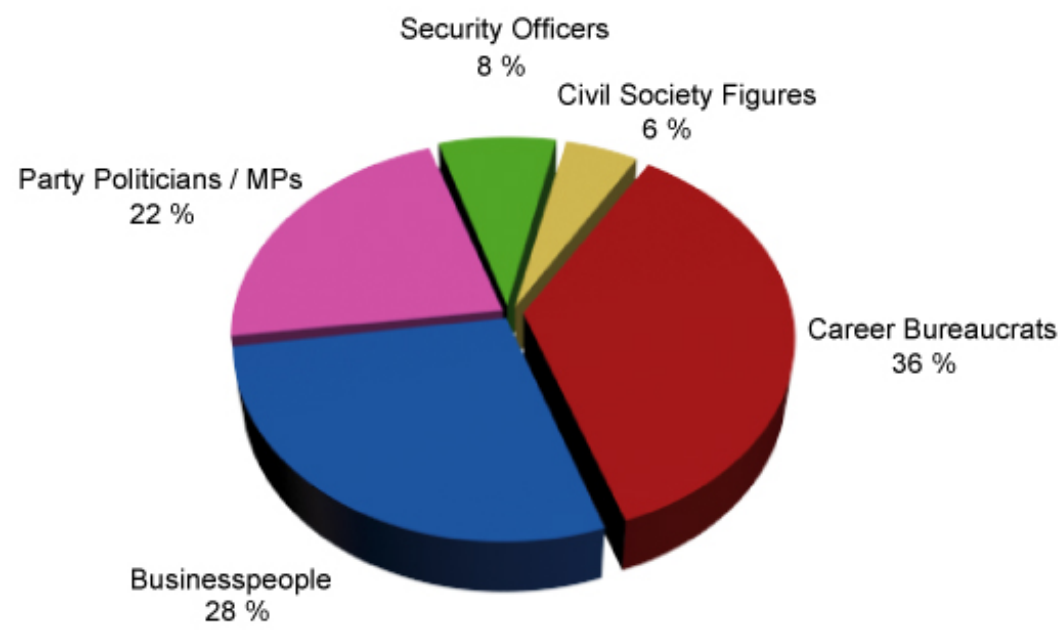

